Tropical Journal of Pharmaceutical Research September 2020; 19 (9): 1835-1842

ISSN: $1596-5996$ (print); 1596-9827 (electronic)

(C) Pharmacotherapy Group, Faculty of Pharmacy, University of Benin, Benin City, 300001 Nigeria.

Original Research Article

http://dx.doi.org/10.4314/tjpr.v19i9.6

\title{
Apoptotic effect of astaxanthin from white shrimp shells on lung cancer A549 cells
}

\author{
Supita Tanasawet ${ }^{1 *}$, Wanida Sukketsiri², Pennapa Chonpathompikunlert ${ }^{3}$, \\ Wanwimol Klaypradit ${ }^{4,5}$, Morakot Sroyraya ${ }^{6}$, Pilaiwanwadee Hutamekalin ${ }^{7}$ \\ ${ }^{1}$ Department of Anatomy, Division of Health and Applied Sciences, Faculty of Science, ${ }^{2}$ Department of Pharmacology, Division \\ of Health and Applied Sciences, Faculty of Science, Prince of Songkla University, Hat Yai, Songkhla 90112, ${ }^{3}$ Expert Centre of \\ Innovative Health Food (InnoFood), Thailand Institute of Scientific and Technological Research (TISTR), Pathumthani, 12120, \\ ${ }^{4}$ Center for Advanced Studies for Agriculture and Food, ${ }^{5}$ Department of Fishery Products, Faculty of Fisheries, Kasetsart \\ University, Bangkok 10900, ${ }^{6}$ Department of Anatomy, Faculty of Science, Mahidol University, Bangkok 10400, ${ }^{7}$ Department of \\ Physiology, Division of Health and Applied Sciences, Faculty of Science, Prince of Songkla University, Hat Yai, Songkhla \\ 90112, Thailand
}

*For correspondence: Email: supita.t@psu.ac.th; Tel: +66 74 288135; Fax: +66 74446663

\begin{abstract}
Purpose: To investigate the anti-cancer potential of astaxanthin from Litopenaeus vannamei encapsulated in liposomes (ASX) to treat lung cancer $A 549$ cells.

Methods: Lung adenocarcinoma A549 cells were cultured and treated with ASX, following which cell viability and nuclear staining were performed. Generation of ROS was identified by the DCFH-DA assay while tetramethylrhodamine ethyl ester was used to determine the mitochondrial membrane potential. Flow cytometry was applied to investigate caspase-3/7 activity and cell cycle distribution.

Results: ASX inhibited growth of A549 in a concentration- and time- dependent manner. The $I C_{50}$ values at 24, 48 and $72 \mathrm{~h}$ were $53.73,22.85,17.46 \mu \mathrm{g} / \mathrm{mL}$, respectively $(p<0.05)$. After incubation with ASX, the morphological changes were observed in A549 cells following Hoechst 33342/PI fluorescent staining. ASX increased ROS generation and was associated with the collapse of mitochondrial membrane potential, which subsequently triggered the activation of caspase- $3 / 7$ activity leading to apoptosis $(p<0.05)$. In addition, A549 cells accumulated in the G0/G1 phase.

Conclusion: The results suggest that ASX is a valuable nutraceutical agent to target $A 549$ lung cancer cells via ROS-dependent pathway as well as blockage of cell cycle progression.
\end{abstract}

Keywords: Astaxanthin, Litopenaeus vannamei, Lung cancer, A549, Apoptosis

This is an Open Access article that uses a fund-ing model which does not charge readers or their institutions for access and distributed under the terms of the Creative Commons Attribution License (http://creativecommons.org/licenses/by/4.0) and the Budapest Open Access Initiative (http://www.budapestopenaccessinitiative.org/read), which permit unrestricted use, distribution, and reproduction in any medium, provided the original work is properly credited.

Tropical Journal of Pharmaceutical Research is indexed by Science Citation Index (SciSearch), Scopus, International Pharmaceutical Abstract, Chemical Abstracts, Embase, Index Copernicus, EBSCO, African Index Medicus, JournalSeek, Journal Citation Reports/Science Edition, Directory of Open Access Journals (DOAJ), African Journal Online, Bioline International, Open-J-Gate and Pharmacy Abstracts

\section{INTRODUCTION}

Lung cancer is one of the major diseases worldwide, the third leading cause of cancerrelated death after breast cancer and prostate cancer. To date, the cause of lung cancer is no longer limited to tobacco smoking. Other contributing factors including diet and food supplements, physical activity, air pollution, have been identified in non-smokers. Epidemiological studies have indicated non-small cell lung cancer 
(NSCLC) to be the predominant type of lung cancer.

Current treatments for NSCLC patients are surgery and adjuvant therapy which may include radiation and chemotherapy. Major toxicities including neutropenia, peripheral neuropathy, nausea and vomiting, nephrotoxicity present as major side effects after chemotherapy [1]. Thus, to develop a potent cancer therapeutic agent with low toxicities and fewer side effects would be desirable. Furthermore, there is an obvious link between diets and human cancers. A number of naturally-occurring substances from antioxidantrich foods are proven to possess a potential role in cancer therapy [2].

Astaxanthin, a potent carotenoid rich with antioxidant activity, mostly found in crustacean shells (e.g. shrimps and crabs), algae, and other marine organisms [3]. In addition to its excellent antioxidant activity, astaxanthin has been reported to possess anti-cancer effects against oral cancer, colon cancer, leukemia and hepatocellular carcinoma [4-6]. More recent studies reported the effects of astaxanthin on the induction of lung cancer cell cytotoxicity and amelioration of lung fibrosis $[7,8]$, thereby drawing a considerable attention.

It has been reported that astaxanthin extracted from the shell of Arabian red shrimp Aristeus alcocki showed a more powerful antioxidant activity than the extract from the green microalgae Haematococcus pluvialis [9]. In addition, free astaxanthin from Litopenaeus vannamei demonstrated a higher percentage $(32.95 \%)$ of anti-oxidant activity than that from Haematococcus pluvialis (5\%) [10].

Nevertheless, the potential use of astaxanthin is often limited due to poor water solubility as well as low bioavailability after oral administration and susceptibility to thermal degradation. These obstacles continue to limit on its therapeutic application in aqueous-based system [11]. Thus, the encapsulation of astaxanthin in nanoliposome, whose structure resembles the lipid membrane of living cells, as carrier system would preserve the native properties of astaxanthin as well as provide its stable aqueous dispersion thus improve its therapeutic potential [12]. Therefore, the present study aimed to investigate the in vitro anti-cancer effects of astaxanthin extracted from white shrimp shells Litopenaeus vannamei and encapsulated in liposomes (ASX) as well as its ability to induce apoptosis and cause cell cycle arrest in human NSCLC A549 cells.

\section{EXPERIMENTAL}

\section{Chemicals}

Dulbecco's modified Eagle's medium (DMEM), Ham's F-12K medium, trypsin/ethylenediaminetetraacetic acid (EDTA), penicillin/streptomycin, L-glutamine and fetal bovine serum (FBS) were obtained from Gibco BRL Life Technologies (NY, USA). Cisplatin, 3-(4,5-Dimethylthiazol-2-yl)-2,5diphenyltetrazolium bromide (MTT), 2',7'dichloro-fluorescein diacetate (DCFH-DA) and Dimethylsulfoxide (DMSO) were purchased from Sigma-Aldrich (MO, USA). Hoechst 33342 and Propidium iodide $(\mathrm{PI})$ were obtained from Cell signaling (MA, USA). Tetramethyl rhodamine ethyl ester (TMRE) was from Abcam (MA, USA). The Muse caspase- $3 / 7$ and cell cycle reagent kits were purchased from Merck Millipore (MA, USA).

\section{Preparation of liposomes containing astaxanthin from white shrimp shells}

Shells of fresh white shrimp (Litopenaeus vannamei) were obtained from a frozen shrimp processing plant in Samut-Sakorn province, Thailand. The shells were then transported to the laboratory within two hours in a cool-Styrofoam box. Astaxanthin was extracted as previously described [13]. To explain briefly, shrimp shells were mixed with ethanol at a ratio of 1:2 in a blender and filtered to collect the extract. The process was repeated three times. Solvent was removed inside a vacuum at $40{ }^{\circ} \mathrm{C}, 175 \mathrm{MPa}$ using a rotary evaporator to obtain the concentrated extract. Astaxanthin loaded in liposome was prepared by the thin-film hydration method [13]. Phospholipids (70\% PC) was dissolved in ethanol $(2.0 \% \mathrm{w} / \mathrm{v})$, then astaxanthin $(2.0 \% \mathrm{w} / \mathrm{v})$ was added. After dissolution, the solution was evaporated in a vacuum at $40{ }^{\circ} \mathrm{C}$. The obtained lipid film was hydrated with water, followed by using an ultrasonic atomizer to obtain the liposome. The sample was stored in the refrigerator $\left(\right.$ at $\left.4{ }^{\circ} \mathrm{C}\right)$ until use.

\section{Cell culture}

Cancer cell lines of human non-small cell lung cancer A549 were purchased from Cell Lines Service (CLS, Eppelheim, Germany) and was grown in Ham's F-12K medium supplemented with $2 \mathrm{mM}$ L-glutamine, $10 \%$ heat-inactivated FBS, $100 \mathrm{U} / \mathrm{mL}$ penicillin, and $100 \mu \mathrm{g} / \mathrm{mL}$ streptomycin, and maintained in a humidified atmosphere at $37^{\circ} \mathrm{C}$ in $5 \% \mathrm{CO}_{2}$. The growth medium was replaced twice a week. After reaching confluence, $0.25 \%$ trypsin/EDTA was used to subculture.

Trop J Pharm Res, September 2020; 19(9): 1836 


\section{Cell viability assay}

Cell viability was determined using MTT assay, which relies on the reduction of yellow tetrazolium salt into purple formazan crystals by mitochondrial dehydrogenases enzymes of viable cells. Briefly, A549 cells were seeded in 96-well culture plates $\left(1 \times 10^{4}\right.$ cells/well). After 24 $\mathrm{h}$ incubation, the cells were exposed to different concentrations of ASX and cisplatin for 24, 48, $72 \mathrm{~h}$, respectively. Then $100 \mu \mathrm{L}$ of MTT reagent $(0.5 \mathrm{mg} / \mathrm{mL})$ was added and incubated for $2 \mathrm{~h}$ at $37^{\circ} \mathrm{C}$. After removing the supernatant, $100 \mu \mathrm{l}$ of DMSO was added to dissolve the precipitate formazan crystals. The optical density (OD) values were then measured with the microplate reader (BioTek, Highland Park, USA) using 570 $\mathrm{nm}$ reference wavelength, and the $\mathrm{IC}_{50}$ values were determined by CompuSyn software.

\section{Hoechst 33342/PI staining and morphological observation}

Apoptosis nuclear morphology was fluorescently probed by Hoechst 3342/PI staining. A549 cells were cultured in 6 -well plates $\left(1 \times 10^{4}\right.$ cells/well) and treated with 25, 50, and $100 \mu \mathrm{g} / \mathrm{mL}$ ASX and cisplatin. Following exposure for $24 \mathrm{~h}$, the cells were double-stained with $10 \mu \mathrm{g} / \mathrm{mL}$ Hoechst 33342 and $2 \mu \mathrm{g} / \mathrm{mL} \mathrm{PI}$ for $30 \mathrm{~min}$ in the dark. The cells were washed with PBS and observed under an inverted fluorescence microscope (Nikon ECLIPSE Ti, Kanagawa, Japan) with excitation at $360 \mathrm{~nm}$ and emission at $465 \mathrm{~nm}$.

\section{Assessment of intracellular reactive oxygen species (ROS)}

Cells treated with $50 \mu \mathrm{g} / \mathrm{mL}$ ASX and cisplatin were grown on 6-well plates in order to quantify the accumulation of intracellular ROS based on the detection of cell permeable DCFH-DA into fluorescent dichlorofluorescein (DCF). After 2 and $4 \mathrm{~h}$ of incubation, the cells were stained with $20 \mu \mathrm{M}$ DCFH-DA for $1 \mathrm{~h}$ at $37^{\circ} \mathrm{C}$ in the dark. After removing the solution, $100 \mu \mathrm{l} /$ well of PBS was added and the fluorescent intensity then measured with a fluorescence microplate reader (BioTek, Highland Park, USA) at excitation 485 $\mathrm{nm}$ and emission $530 \mathrm{~nm}$.

\section{Assessment of the alterations of mitochondrial membrane potential (MMP)}

Mitochondrial membrane potential was performed using TMRE mitochondrial membrane potential assay kit (Abcam, Ab113852) in order to label the active mitochondria. A549 cells were cultured and treated with $50 \mu \mathrm{g} / \mathrm{mL}$ ASX and cisplatin. Subsequently, the cells were stained with TMRE at $37^{\circ} \mathrm{C}$ for 20 min in the dark and the TMRE intensity was fluorescently analyzed by a fluorescence microplate reader with an excitation of $549 \mathrm{~nm}$ and emission of $575 \mathrm{~nm}$ (BioTek, Highland Park, USA).

\section{Caspase-3/7 activity assay}

A549 cells were plated at $1 \times 10^{6}$ cells $/ \mathrm{mL}$ and were allowed to adhere for $24 \mathrm{~h}$. After the cells were incubated with or without ASX, caspase-3/7 activity was evaluated by Muse Caspase-3/7 assay kit (Merck, MCH100108). The Muse caspase-3/7 working solution was added to the collected cells and incubated at $37^{\circ} \mathrm{C}$ for $20 \mathrm{~min}$. Prior to analyzing with a Muse ${ }^{\circledR}$ cell analyzer, 7$A A D$ was added and incubated at room temperature in the dark. The caspase- $3 / 7$ assay was demarcated into four quadrants representing the percentage of cells that undergo live, early apoptosis, late apoptosis, or dead.

\section{Cell cycle analysis}

Cell cycle alteration was investigated by flow cytometry assay using a Muse cell cycle kit (Merck, MCH100106). Cells were seeded at a density of $1 \times 10^{6}$ cells $/ \mathrm{mL}$ in 6 -well plates, treated with or without ASX for $24 \mathrm{~h}$. After the cells were fixed with ice cold $70 \%$ ethanol, the cells were incubated at $-20^{\circ} \mathrm{C}$ for $4 \mathrm{~h}$. Subsequently, Muse cell cycle reagent was added to the cells and incubated for $30 \mathrm{~min}$ at room temperature in the dark. Cell cycle distribution was then analyzed by the Muse $®$ cell analyzer.

\section{Statistical analysis}

The results are expressed as the standard error of the mean (SEM) of at least three independent experiments. The data were analyzed by oneway ANOVA using SPSS13 software. $P<0.05$ was considered to indicate statistically significant differences from the control.

\section{RESULTS}

\section{Astaxanthin inhibited the growth of lung cancer A549 cells}

Human non-small cell lung cancer A549 cell line was exposed to $0-100 \mu \mathrm{g} / \mathrm{mL}$ of ASX for 24,48 and $72 \mathrm{~h}$ and was investigated for viability using MTT assay. As shown in Figure $1 \mathrm{~A}$, ASX induced concentration- and time- dependent growth inhibitory effects. The half-maximal inhibitory concentration $\left(\mathrm{IC}_{50}\right)$ value at 24,48 , and $72 \mathrm{~h}$ was $53.73 \pm 4.03,22.85 \pm 1.86,17.46 \pm$ $2.96 \mu \mathrm{g} / \mathrm{mL}$, respectively. In addition, the viability 
of A549 cells treated with a positive control drug cisplatin for 24,48 , and $72 \mathrm{~h}$ was significantly inhibited in a concentration- and time-dependent fashion with the $\mathrm{IC}_{50}$ value of $9.54 \pm 3.60,2.96 \pm$ $2.89,2.09 \pm 1.73 \mu \mathrm{g} / \mathrm{mL}$ as presented in Figure 1 $B$. The $\mathrm{IC}_{50}$ value obtained from $\mathrm{ASX}$ and cisplatin at $24 \mathrm{~h}$ was used for subsequent experiments.

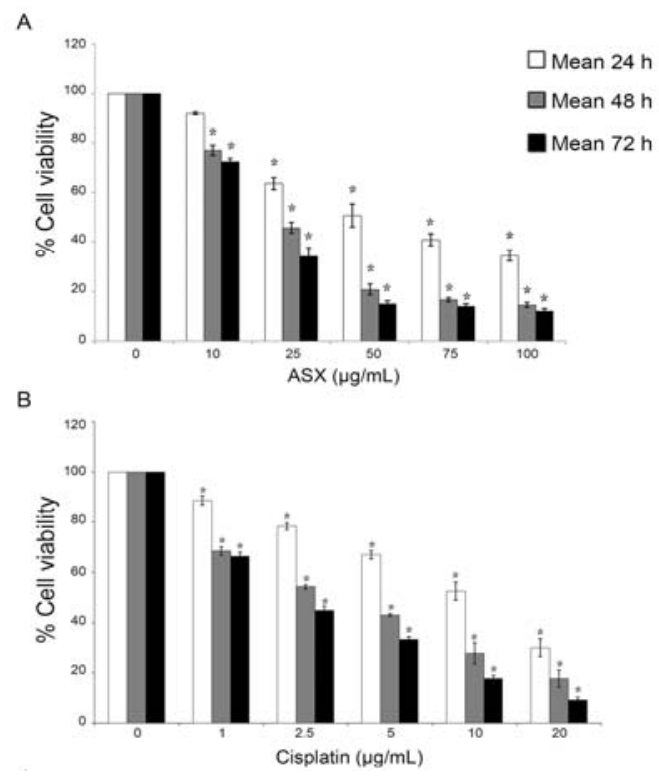

Figure 1: Effect of astaxanthin from white shrimp shells (ASX) on the viability of human non-small cell lung cancer A549 cells as determined by MTT assay. (A) Treatment of A549 cells with ASX for 24, 48 and 72 h. (B) Treatment of A549 cells with the chemotherapeutic drug cisplatin for 24,48 and $72 \mathrm{~h}$. Data are representative of mean \pm SEM of three independent experiments; ${ }^{*} p<0.05$ compared to the control

\section{Astaxanthin altered lung cancer A549 cell morphology}

Morphological examination of cell death after treatment with ASX was investigated in this study by both phase contrast microscopy and nuclear staining with Hoechst/PI. Phase contrast microscopy revealed that ASX induced cell death in A549 cells in comparison to the untreated control (Figure 2 A). Distinctive morphological alterations including the loss of cell processes and cell contact thereby detaching from the surface of culture plates, more rounded morphology, and reduction of viable cells were observed in various concentrations of ASX (25, 50 and $100 \mu \mathrm{g} / \mathrm{mL}$ ) and cisplatin treatment. Nuclear morphological alteration was visualized by using the blue fluorescent dye of Hoechst 33342 which selectively binds to AT region of the DNA in order to confirm the chromatin condensation of apoptotic nuclei. The red fluorescent dye of $\mathrm{PI}$, which is impermeable to the viable cell membranes, was counter-stained to determine the necrosis cells. Upon treatment with 25, 50, and $100 \mu \mathrm{g} / \mathrm{mL}$ ASX, A549 cells demonstrated the bright blue nuclear staining of chromatin condensation and fragmentation as well as cell decrement in a concentrationdependent manner as shown in Figure $2 \mathrm{~B}$. This was similar to the result obtained from cisplatin treatment. In contrast to the untreated control, the nuclei showed a typical uniformly dispersed chromatin with normal nuclear morphology. This finding validated the apoptotic characteristic of lung cancer A549 cells after treatment with ASX and cisplatin.
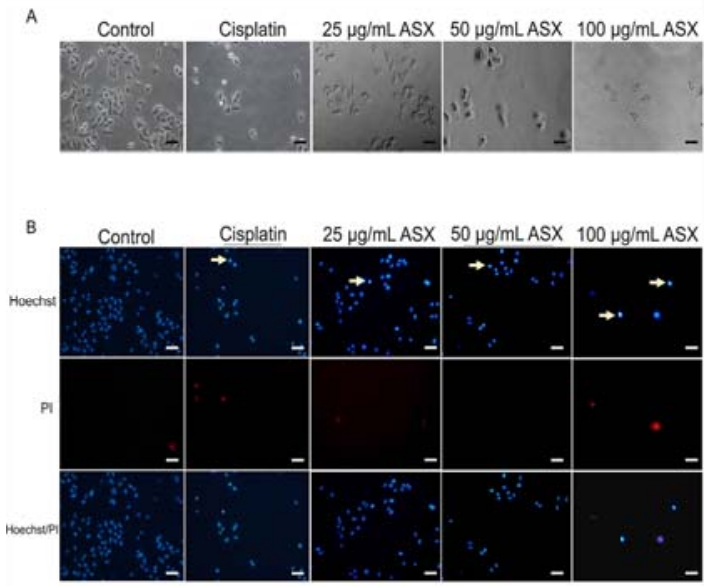

Figure 2: Effect of astaxanthin from white shrimp shells (ASX) on morphological alterations of A549 cells. (A) A549 cells were treated with cisplatin and 25, 50 and $100 \mu \mathrm{g} / \mathrm{mL}$ ASX for $24 \mathrm{~h}$ and visualized under phase contrast microscope. (B) A549 cells were treated with cisplatin and 25, 50 and $100 \mu \mathrm{g} / \mathrm{mL}$ ASX for $24 \mathrm{~h}$ and stained with Hoechst 33342/PI and visualized under fluorescence microscope. Scale bar: $40 \mu \mathrm{m}$

\section{Astaxanthin induced ROS generation in lung cancer A549 cells}

To better understand the underlying mechanism of ASX-mediated apoptosis of A549 cells, the intracellular ROS which is the key signaling molecule in apoptosis was investigated by fluorescently probing with oxidation-sensitive DCFH-DA. Treatment with $\mathrm{IC}_{50}$ of $\mathrm{ASX}$ and cisplatin for $4 \mathrm{~h}$ caused a significant increase in the intracellular ROS level $(p<0.05)$ as shown in Figure $3 \mathrm{~A}$. In comparison with the untreated control $(100 \%), 195 \%$ ROS was generated in the A549 cells treated with ASX and $144 \%$ when treated with cisplatin. However, treatment with ASX (134\%) or cisplatin (130\%) for $2 \mathrm{~h}$ showed 
no significant difference from the control of ROS generation.

Astaxanthin induced loss of mitochondrial membrane potential (MMP) in lung cancer A549 cells

To explore the possible anti-cancer role of ASX against lung cancer A549 cells associated with MMP by TMRE-labeled active mitochondria. As shown in Figure $3 \mathrm{~B}$, exposure of A549 cells to ASX for $24 \mathrm{~h}$ triggered a significant disruption of mitochondrial membrane potential with $73 \%$ compared to the control $(p<0.05)$. Cisplatin treated lung cancer A549 cells (positive control) also demonstrated a significant reduction of mitochondrial membrane potential with $69 \%(p<$ 0.05 ). Our data suggested that ASX induced the loss of MMP of A549 cells via ROS-mediated pathway.

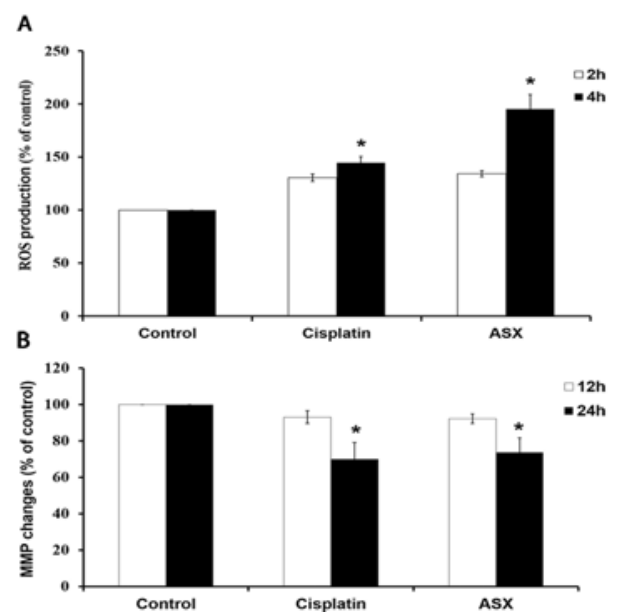

Figure 3: Effect of astaxanthin from white shrimp shells (ASX) on intracellular reactive oxygen species (ROS) level and mitochondrial membrane potential (MMP) in A549 cells. (A) Intracellular ROS level was analyzed by DCF assay after treatment with cisplatin and ASX; (B) MMP was analyzed by TMRE assay after treatment with cisplatin and ASX. Data are representative of mean \pm SEM of three independent experiments; ${ }^{*} p<0.05$ compared to the control

\section{Astaxanthin induced caspase-3/7 activity in lung cancer A549 cells}

The involvement of caspase- $3 / 7$ which is activated during the process of caspasedependent apoptosis was also determined. A549 cells were treated with 50 and $100 \mu \mathrm{g} / \mathrm{ml}$ ASX for $24 \mathrm{~h}$, and caspase- $3 / 7$ activity was monitored by flow cytometry. Representative profile from flow cytometry was demonstrated into four quadrants: viable cells (lower left quadrant: caspase-3/7 - /7AAD -), necrosis (upper left quadrant: caspase3/7 - /7-AAD +), early apoptosis (lower right quadrant: caspase-3/7 + /7-AAD -), and late apoptosis (upper right quadrant: caspase-3/7 + 17-AAD +). Thereafter, the percentage of total apoptotic cells via caspase-3/7 activation was also quantitatively demonstrated. As shown in Figure $4 \mathrm{~A}$, the untreated control A549 cells represented in a lower left quadrant indicating live cells. Upon exposing A549 cells to $50 \mu \mathrm{g} / \mathrm{mL}$ ASX, an increased caspase-3/7 activity in the lower and upper right quadrant were observed (Figure $4 \mathrm{~B}$ ). By increasing the dosage of ASX to $100 \mu \mathrm{g} / \mathrm{mL}$, a gradual activation of caspase-3/7 was shown in Figure $4 \mathrm{C}$. The percentage of caspase- $3 / 7$ activation by ASX was $31.26 \pm 2.49$ and $35.55 \pm 3.70$ for the concentration of 50 and $100 \mu \mathrm{g} / \mathrm{mL}$ ASX, respectively, and was shown to increase significantly $(p<0.05)$ when compared to the control, as demonstrated in Figure $4 \mathrm{D}$.

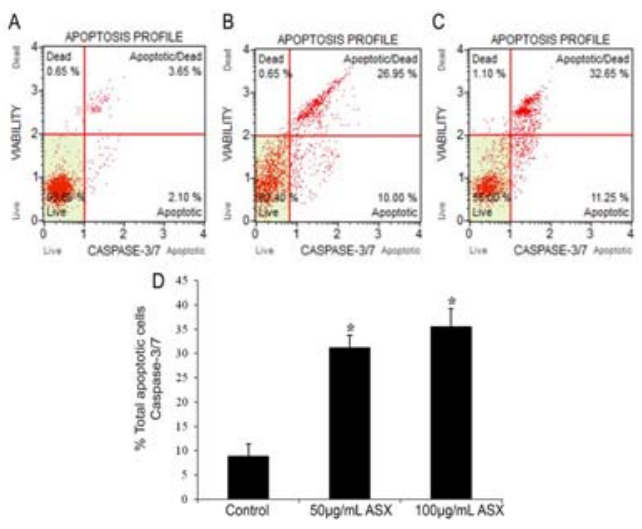

Figure 4: Effect of astaxanthin from white shrimp shells (ASX) on caspase- $3 / 7$ activity in A549 cells by Muse $®$ caspase- $3 / 7$ assay. (A) Representative dot plot of caspase-3/7 activity of the control; (B) Representative dot plot of caspase-3/7 activity of cells treated with $50 \mu \mathrm{g} / \mathrm{mL}$ ASX; (C) Representative dot plot of caspase-3/7 activity of cells treated with 100 $\mu \mathrm{g} / \mathrm{mL}$ ASX; (D) The percentage of caspase- $3 / 7$ activation at different concentration of 50 and 100 $\mu \mathrm{g} / \mathrm{mL}$ ASX in A549 cells. Data are representative of mean \pm SEM of three independent experiments. ${ }^{*} p<$ 0.05 compared to the control

\section{Astaxanthin induced G0/G1 phase arrest in lung cancer A549 cells}

To further verified whether the treatment with ASX influences the cell cycle distribution in A549 cells by Muse ${ }^{\circledR}$ cell analyzer. Our result indicated that treatment of cells with 50 and 100 $\mu \mathrm{g} / \mathrm{mL}$ ASX for $24 \mathrm{~h}$ caused a significant accumulation of cells in G0/G1 phase of cell cycle (Figure $5 \mathrm{~B}, \mathrm{C}$ and $\mathrm{D}$ ) with a concomitant decrease of cells in $S$ and G2/M phase compared to the untreated control (Figure $5 \mathrm{~A}$ ). As summarized in Figure 5D, the cell cycle distribution of A549 cells in G0/G1 phase after treatment with ASX (50 and $100 \mu \mathrm{g} / \mathrm{mL}$ ) was 
69.73 and $70.67 \%$, respectively, compared to the control $(65.13 \%)$, indicating the role of ASX induced G0/G1 phase arrest in human lung cancer A549 cells.

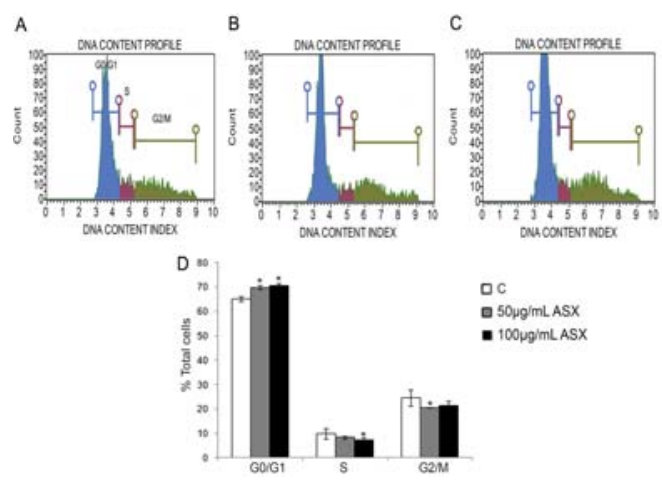

Figure 5: Effect of astaxanthin from white shrimp shells (ASX) on cell cycle distribution in A549 cells by Muse $\AA$ cell cycle kit. (A) Representative histogram of DNA content of the control; (B) Representative histogram of DNA content of cells treated with 50 $\mu \mathrm{g} / \mathrm{mL}$ ASX; (C) Representative histogram of DNA content of cells treated with $100 \mu \mathrm{g} / \mathrm{mL}$ ASX; (D) The percentage of cells in G0/G1, S and G2/M phases of the cell cycle at different concentration of 50 and 100 $\mu \mathrm{g} / \mathrm{mL}$ ASX in A549 cells. Data are representative of mean \pm SEM of three independent experiments; ${ }^{*} p<$ 0.05 compared to the control

\section{DISCUSSION}

One major challenge of the discovery of cancer therapeutic agents is to trigger the programmed cell death or apoptosis signaling pathway. The present study used astaxanthin from Litopenaeus vannamei encapsulated in liposome to induce human NSCLC A549 cells apoptosis through ROS-dependent pathway and the blockage of cell cycle progression. First, the capacity of ASX on the growth inhibitory effect against lung cancer A549 cells was evaluated by the MTT assay. ASX demonstrated anti-cancer activity by inhibiting the growth of lung cancer cell line A549 in a concentration- and time-dependent manner, which is consistent with a recent study that reported the effect of astaxanthin on the inhibition of two NSCLC cell lines, A549 and H1703 cell viability [7].

A similar finding from Song and colleagues [5] demonstrated the potential role of astaxanthin on the inhibition of hepatocellular carcinoma CBRH7919 cells proliferation. So, it is possible to note that the marine naturally occurring compound astaxanthin possesses as a potent cytotoxicity to the cancer cells $[3,14,15]$. Among the chemotherapeutic drugs targeting lung cancer, cisplatin has been employed and found to trigger lung cancer cell death [16]. Also, we reported the growth inhibitory effect of a positive control drug cisplatin against A549 cells in this study.

Secondly, we verified whether the cytotoxic effect of ASX was associated with the apoptosis morphological characteristics on lung cancer cells. If cells undergo apoptosis, a series of cellular changes including cell shrinkage, nuclear fragmentation, and chromatin condensation would be observed [17]. Based on DNA-binding fluorescence staining, the brightly stained chromatin condensation and fragmentation demonstrated after ASX and cisplatin exposure in A549 cells suggest the correlation with the apoptotic morphology. However, the number of dead cells with late apoptosis or necrosis visualized by $\mathrm{Pl}$ staining was observed in response to a high concentration of ASX (100 $\mu \mathrm{g} / \mathrm{mL}$ ) treatment.

Apoptosis is triggered by various types of stimuli either extrinsic or intrinsic signal transduction. ROS has been reported as key mediators during apoptosis machinery and is implicated in the regulation of intrinsic apoptosis pathway $[17,18]$. With regards to DCFH-DA assay, which probes the intracellular ROS level, we found that the accumulation of ROS in A549 cells was increased in response to the treatment with 100 $\mu \mathrm{g} / \mathrm{mL}$ ASX and $10 \mu \mathrm{g} / \mathrm{mL}$ cisplatin for $4 \mathrm{~h}$. The result pointed to the probability that ROS would interplay in the early event of apoptosis, which is in accordance with previous literature [19].

Further analysis also focused on mitochondria, which are a major site for ROS production as well as maintenance of cellular redox and energy homeostasis. ASX caused the disruption of MMP based on TMRE assay and subsequent activation of cysteine proteases caspase-3/7 activity. Following the disruption of mitochondrial membrane potential, the mitochondrial proapoptotic factors were released into the cytosol resulting in the formation of apoptosome which activated the executioner caspase-3/7. The activated caspase-3/7 cleaved nuclear lamin causing the breakdown of the nucleus which ultimately led to morphological and biochemical characteristic of apoptosis [20]. The present findings thus suggest the execution of apoptosis cell death via caspase-dependent mitochondrial pathway induced by ASX treatment.

Understanding the relationship between cell cycle and lung cancer as a target of antineoplastic drug is beneficial [21]. This study demonstrated ASX induced a G0/G1 phase arrest accompanied with the reduction of cells in $S$ and G2/M phases of the cell cycle in the lung cancer A549 cells. This was in accordance with previous report examining astaxanthin from 
shrimp, which showed an accumulation of cells in G0/G1 phase in human breast adenocarcinoma MCF-7 cell line [22]. Cell cycle was monitored by the checkpoint proteins including the cyclin D which was the first cyclin produced in the cell cycle. The formation of cyclin D/cyclin dependent kinase $(C D K)$ is required in DNA replication and mitosis associated with the transition of the cell cycle. Recent finding suggested that the mechanism of G0/G1 blockage might be from the downregulation of $\mathrm{p}$-ERK subsequently inhibiting cyclin D1/CDK4 protein complex [23].

\section{CONCLUSION}

Taken together, the present study provides the evidence of intrinsic apoptotic signaling pathway initiated by ROS, thereby mediating mitochondrial/caspase-dependent cascade and ultimately G0/G1 cell cycle arrest in human lung cancer A549 cells by ASX treatment. Thus, ASX could be further developed as a potential chemotherapeutic agent for lung cancer in the future.

\section{DECLARATIONS}

\section{Acknowledgement}

The study was supported by a grant from the General Project and Invention of Prince of Songkla University (no. SCl610525S), Graduate School of Prince of Songkla University, Songkhla, Thailand. Authors would like to thanks to Mrs Wichuda McConnell from publication clinic, Prince of Songkla University for the English revision.

\section{Conflict of interest statement}

No conflict of interest is associated with this work.

\section{Contribution of authors}

We declare that this work was done by the authors listed in this article and all liabilities related to the content of this article will be borne by the authors. ST designed and performed the experiments as well as wrote the manuscript. WS and PC participated in the design of the experiment and provided the intellectual comments to this study. WS also involved in cell culture experiment. WK prepared liposomes containing astaxanthin from white shrimp shells. MS involved in the microscopic technique. $\mathrm{PH}$ participated in cell cycle experiment. All authors read and approved the final manuscript.

\section{Open Access}

This is an Open Access article that uses a funding model which does not charge readers or their institutions for access and distributed under the terms of the Creative Commons Attribution License (http://creativecommons.org/licenses/by/ 4.0) and the Budapest Open Access Initiative (http://www.budapestopenaccessinitiative.org/rea d), which permit unrestricted use, distribution, and reproduction in any medium, provided the original work is properly credited.

\section{REFERENCES}

1. Molina JR, Yang P, Cassivi SD, Schild SE, Adjei AA. Non-small cell lung cancer: epidemiology, risk factors, treatment, and survivorship. Mayo Clin Proc 2008; 83: 584-594. https://doi.org/10.4065/83.5.584

2. Borek C. Dietary antioxidants and human cancer. Integr Cancer Ther 2004; 3: 333-341. doi: 10.1177/1534735404270578

3. Ambati RR, Phang SM, Ravi S, Aswathanarayana RG. Astaxanthin: sources, extraction, stability, biological activities and its commercial applications-a review. Mar Drugs 2014; 12: 128-152. doi: 10.3390/md12010128

4. Palozza P, Torelli C, Boninsegna A, Simone R, Catalano A, Mele MC, Picci N. Growth-inhibitory effects of the astaxanthin-rich alga Haematococcus pluvialis in human colon cancer cells. Cancer Lett 2009; 83: 108-117.

5. Song X, Zhang J, Wang M, Liu W, Gu X, Lv CJ. Astaxanthin induces mitochondria-mediated apoptosis in rat hepatocellular carcinoma CBRH-7919 cells. Biol Pharm Bull 2011; 34: 839-844.

6. Zhang $L$, Wang $H$. Multiple mechanisms of anti-cancer effects exerted by astaxanthin. Mar Drugs 2015; 13 : 4310-4330. https://doi.org/10.3390/md13074310

7. Ko JC, Chen JC, Wang TJ, Zheng HY, Chen WC, Chang PY, Lin YW. Astaxanthin down-regulates Rad51 expression via inactivation of AKT kinase to enhance mitomycin C-induced cytotoxicity in human non-small cell lung cancer cells. Biochem Pharmacol 2016; 105: 91-100. doi: 10.1016/j.bcp.2016.02.016

8. Wang $M$, Zhang J, Song $X$, Liu W, Zhang L, Wang $X, L v$ C. Astaxanthin ameliorates lung fibrosis in vivo and in vitro by preventing transdifferentiation, inhibiting proliferation, and promoting apoptosis of activated cells. Food Chem Toxicol 2013; 56: 450-458. doi: 10.1016/j.fct.2013.03.004

9. Kavitha K, Kowshik J, Kishore TK, Baba AB, Nagini S. Astaxanthin inhibits NF-KB and Wnt/ $\beta$-catenin signaling pathways via inactivation of ErK/MAPK and PI3K/Akt to induce intrinsic apoptosis in a hamster model of oral cancer. Biochim Biophys Acta 2013; 1830: 4433-4444. doi: 10.1016/j.bbagen.2013.05.032

10. Miao F, Lu D, Li Y, Zeng M. Characterization of astaxanthin esters in Haematococcus pluvialis by liquid chromatography-atmospheric pressure chemical

Trop J Pharm Res, September 2020; 19(9): 1841 
ionization mass spectrometry. Anal Biochem 2006; 352(2): 176-181.

11. Suntres ZE. Liposomal antioxidants for protection against oxidant-induced damage. J Toxicol 2011; 2011: 152474. https://doi.org/10.1155/2011/152474

12. Monteiro N, Martins A, Reis RL, Neves NM. Liposomes in tissue engineering and regenerative medicine. $J R$ Soc Interface 2014; 11: 20140459.

13. Sangsuriyawong $A$, Limpawattana $M$, Sririwan $D$, Klaypradit $W$. Properties and bioavailability assessment of shrimp astaxanthin loaded liposomes. Food Sci Biotechnol 2019;28(2):529-537.

14. Glasauer A, Chandel NS. Targeting antioxidants for cancer therapy. Biochem Pharmacol 2014; 92: 90-101.

15. Tanaka $T$, Shnimizu M, Moriwaki $H$. Cancer chemoprevention by carotenoids. Molecules 2012; 17(3): 3202-3242.

16. Cortés ÁA, Urquizu LC, Cubero JH. Adjuvant chemotherapy in non-small cell lung cancer: state-ofthe-art. Transl lung cancer Res 2015; 4: 191-197.

17. Ziegler $U$, Groscurth P. Morphological features of cell death. News Physiol Sci 2004; 19:124-128.
18. Fleury $C$, Mignotte $B$, Vayssière $J L$. Mitochondrial reactive oxygen species in cell death signaling. Biochimie 2002; 84: 131-141.

19. Li Z, Dong $X$, Liu $H$, Chen $X$, Shi $H$, Fan $Y$, Zhang $X$. Astaxanthin protects ARPE-19 cells from oxidative stress via upregulation of Nrf2-regulated phase II enzymes through activation of PI3K/Akt. Mol Vis 2013; 19: 1656-1666.

20. Gogvadze V, Orrenius S, Zhivotovsky B. Mitochondria as targets for chemotherapy. Apoptosis 2009; 14: 624-640. doi: 10.1007/s10495-009-0323-0

21. Williams $\mathrm{GH}$, Stoeber $K$. The cell cycle and cancer. J Pathol 2012; 226: 352-364. doi: 10.1002/path.3022

22. Sowmya $P R$, Arathi BP, Vijay $K$, Baskaran V, Lakshminarayan R. Astaxanthin from shrimp efficiently modulates oxidative stress and allied cell death progression in MCF-7 cells treated synergistically with B-carotene and lutein from greens. Food Chem Toxicol 2017; 106: 58-69.

23. Kim JH, Park JJ, Lee BJ, Joo MK, Chun HJ, Lee SW, Bak YT. Astaxanthin inhibits proliferation of human gastric cancer cell lines by interrupting cell cycle progression. Gut Liver 2016; 10: 369-374. 